\title{
The Appropriation by German Courts in French-occupied Baden of Control Council Law No. 10's Definition of Crimes against Humanity in the Prosecution of Nazi-era Defendants, 1946-1951
}

Michael S. Bryant

The story of the Allies' prosecution of Nazi war criminals after World War II has been exhaustively researched, generating scores of books, articles, and films that have documented the process whereby the Allies established the International Military Tribunal at Nuremberg to try top-ranking Nazi war criminals, while leaving to national courts scattered across Europe the responsibility for prosecuting German offenders in the countries in which they had perpetrated their crimes. A subject that has received less attention is the German judiciary's reconstitution as a partner with the Allies in prosecuting Nazi war criminals after the fall of the Nazi government in May 1945. In this essay, I will examine the history of the German judiciary's reconstitution as an instrument for punishing Nazi war criminals immediately after the war. We will trace the interweaving of German law and the law of the Allied Control Council, especially Control Council Law No. 10 (enacted in December 1945), in the jurisprudence of German courts in the French occupied zone of Baden. As we do, we will see that, despite formal restrictions on German jurisdiction, Law No. 10 empowered Baden courts to prosecute a broad spectrum of Nazi crimes as Crimes against $\mathrm{Hu}$ manity until the early 1950 s.

Already before the German surrender, the Allies had drawn up plans to purge German society of National Socialist elements and prevent Germany from waging future wars. At the Yalta Conference in February 1945, they had decided to partition the country and its capital into four separate zones of occupation. In April, the U.S. Joint Chiefs of Staff pursued this policy of weakening postwar Germany by issuing JCS Directive 1067, a decree that reasserted the USA's intention to demilitarize, de-Nazify, de-centralize, and democratize the country. JCS 1067 also announced the closure of all German courts and the disbanding of all "extraordinary" and Nazi Party courts. Accordingly, after Germany's unconditional surrender in May 1945, the Allies suspended the operation of all German courts until the judiciary could be purged of National Socialist influences. At Potsdam 
in July 1945, the future shape of the German court system became clearer when the Allies declared it would be "reorganized in accordance with the principles of democracy, of justice under law, and of equal rights for all citizens without distinction of race, nationality, or religion." ${ }^{1}$

The Allies' plan was to reopen German courts once they had been scoured of former Nazi officials and "brown" ideology. After the Allied Control Council had repealed discriminatory legal measures adopted during the era of the Third Reich, ${ }^{2}$ it promulgated in late October 1945 Control Council Law No. 4 on the "Reorganization of the Judicial System," designed to create the basis for a uniform reconstitution of the German court system in each of the three western zones of occupation. Law No. 4 restored the system of ordinary courts as it existed prior to Hitler's appointment as chancellor, consisting of district (Amtsgerichte), state (Landgerichte), and appellate (Oberlandesgerichte) courts. ${ }^{3}$ Law No. 4 reasserted the traditional pre-1933 criminal jurisdiction of each of these courts: the district courts could impose prison terms up to five years; the state courts had jurisdiction over all cases beyond the competency of the district courts, and presided over appeals from the district courts on both factual and legal grounds; and the appellate courts reviewed appeals from the state courts but on legal grounds alone. Law No. 4, however, denied to the newly reestablished German courts jurisdiction over offenses committed by Germans against the allied occupation forces or citizens of allied nations and their property. It also deprived German courts of jurisdiction over crimes committed by allied soldiers or their nationals. ${ }^{4}$

1 Karl Loewenstein, "Reconstruction of the Administration of Justice in AmericanOccupied Germany," Harvard Law Review 61 (1948), 419-420; Henry Friedlander, "The Judiciary and Nazi Crimes in Postwar Germany," Simon Wiesenthal Center Annual 1 (1984), 27-28.

2 Control Council Law No. 1 (20 September 1945), cited in Friedlander, 28. As Loewenstein notes, both the Potsdam Declaration and JCS 1067 provided for the repeal of "peculiarly Nazi legislation." Loewenstein, 420. Control Council Law No. 1 reified the Allied intention to de-Nazify German law, announced as early as April 1945.

3 The Reichsgericht, the German Supreme Court before May 1945, was the fourth type of ordinary court in Germany. Dissolved with Germany's formal surrender in May 1945, it was succeeded by the Bundesgerichtshof when the Federal Republic of Germany came into existence in 1949.

4 Eli E. Nobleman, "The Administration of Justice in the United States Zone of Germany," Federal Bar Journal 8 (1946), 92-94; Loewenstein, 422-428; Michael S. Bryant, "Back into the Unmasterable Past: Southwest Germany and the Judicial Odyssey of Mayor Reinhard Boos, 1947-1949," Human Rights Review 8.3 (2007); 
Beyond the revival of the district, state, and appellate court system which had existed before 1933, Law No. 4 did not clarify precisely how the reorganization it contemplated should be effected; presumably, implementing the law's terms would be left to the discretion of the various Allied commanders in their zones of occupation. What was clear, however, was Law No. 4's denial of German jurisdiction over Nazi crimes, insofar as these were understood as targeting Allied citizens. ${ }^{5}$ The Allied Control Council modified its stance on this issue with the proclamation of Law No. 10 in December 1945. A primary purpose of Law No. 10 was to forge a uniform basis for national (or "zonal") trials, to be conducted by each of the four powers in its own zone of occupation. As Henry Friedlander has observed, the Allies intended to use Law No. 10 to prosecute Germans in Allied proceedings. ${ }^{6}$ For this reason, two of the three crimes that Law No. 10 promulgated-namely, "Crimes against Peace" and "War Crimes"were clearly outside the jurisdiction of German courts, inasmuch as these crimes involved acts of violence inflicted by Germans on non-German nationals. ${ }^{7}$ Regarding the $3^{\text {rd }}$ of the three offenses under Law No. 10, however, the Control Council left open the door to German jurisdiction. The third offense was "Crimes against Humanity," modeled to a large extent on the IMT Charter's definition set forth in Article 6 (c). Article II of CCL No. 10 defined Crimes against Humanity as follows:

Atrocities and offenses, including but not limited to murder, extermination, enslavement, deportation, imprisonment, torture, rape, or other inhumane acts committed against any civilian population, or perse-

Friedlander, 28; Adalbert Rückerl, The Investigation of Nazi Crimes 1945-1978 (Hamden, CT: Archon Books, 1980), 34.

5 See Article III of Control Council Law No. 4, excerpted in Rückerl, 33: “... jurisdiction of German courts shall extend to all cases both civil and criminal” except for "criminal offenses committed by Nazis or any other persons against citizens of Allied nations and their property, as well as attempts directed towards the reestablishment of the Nazi regime, and the activity of the Nazi organizations."

6 Friedlander, 31.

7 Two sources of law stymied German jurisdiction over Crimes against Peace and War Crimes: (1) the requirement under the Laws of Armed Conflict that jurisdiction over war crimes existed only where there was a diversity of nationality between defendant and victim; and (2) the prohibition in CCL No. 4, sustained in CCL No.10, which forbade German courts from presiding over Nazi crimes perpetrated on the soldiers and civilians of Allied countries. See CCL No. 10, section 1, paragraph (d), Appendix D to Telford Taylor, Final Report to the Secretary of the Army, CD-ROM (Seattle, WA: Aristarchus Knowledge Industries, 1995). 
cutions on political, racial, or religious grounds whether or not in violation of the domestic laws of the country where perpetrated. ${ }^{8}$

Law No. 10 permitted each of the occupying powers to arrest individuals suspected of such crimes and to try them in "an appropriate tribunal." Further, the Law indicated that the occupying authority could entrust jurisdiction over Crimes against Humanity to a German court when both the perpetrators and the victims were German nationals or "stateless persons."

For the newly reestablished German judiciary after 1945, CCL No. 10 held two important implications. First, the Law's restriction meant that German courts were denied jurisdiction over the crimes of the Final Solution until German courts were forbidden by the Control Council to apply Law No. 10 after August 1951. Thereafter, they could only apply German criminal law in the trials of accused Nazi perpetrators. Second, the Law enabled the French, British, Americans, and Soviets to authorize German courts in their zones to try German defendants for Crimes against Humanity under CCL No. 10, so long as the victims were Germans or stateless persons. In fact, those German courts designated by the zonal authority as tribunals "appropriate" to try German defendants under CCL No. 10 had little choice but to prosecute these offenses as Crimes against Humanity. In some instances, such as where Law No. 10's definition of Crimes against Humanity did not fully embrace the elements of the alleged offense, the German court could charge a defendant with both a Crime against Humanity and an additional offense under German law. Consequently, in zones of occupation (like the French and British) in which German courts were required to charge their Nazi war criminals with Crimes against Humanity under Law No. 10, ${ }^{9}$ criminal indictments issued between 1946 and 1951 reflect a strange admixture of Control Council, international humanitarian, and German domestic law.

In charging Nazi defendants under CCL No. 10, German prosecutors enjoyed advantages denied them under German law. Unlike the provisions of the German penal code, Law No. 10 was based on the Anglo-American law of conspiracy, and thus did not recognize a distinction between perpetrators and accomplices: all participants in the crime were jointly liable as perpetrators for any acts carried out in furtherance of it. Another significant difference was Law No. 10's relative disregard of subjective factors in its deliberations on a defendant's guilt. Under Law No. 10, such issues as the defendant's consciousness of wrongdoing, developmental background,

8 Excerpted in Friedlander, 31.

9 See Rückerl, 40. 
or state of mind at the time of the offense, were immaterial. All that counted was that the defendant intentionally committed or helped commit an act condemned by Law No. 10, i.e., murder, extermination, enslavement, deportation, or political, racial, or religious persecution, all directed against "any civilian population." If the defendant was found to have committed any of these acts, regardless of the degree of his participation, he was guilty as a perpetrator of a Crime against Humanity. ${ }^{10}$ Other advantages that CCL No. 10 offered was a broader range of penalties than those prescribed in the German penal code: where the maximum punishment under German law (other than death and a life sentence) was capped at 15 years, CCL No. 10 enabled courts to impose sentences for any term of years, including life. Finally, courts could convict defendants under Law No. 10 for actions unrecognized as illegal under German law, such as "crimes of denunciation" (Denunziantenverbrechen), a species of wrongdoing that encompassed both persons who had denounced the Stauffenberg conspirators in July 1944 as well as the "grudge informers" who had turned in their neighbors to the authorities for listening to foreign radio broadcasts or disparaging Hitler. Crimes of denunciation also extended to German men whose acts of divorcing their Jewish wives had doomed them to deportation to the East. ${ }^{11}$

Control Council Laws No. 4 and No. 10 established the boundaries of justiciability of Nazi crimes in German courtrooms. Article II of CCL No.10, we will recall, had envisioned prosecuting as Crimes against $\mathrm{Hu}-$ manity two basic kinds of offense: crimes of the "murder type," which embraced homicide, extermination, enslavement, deportation, etc.; and those of the "persecution type," that is, crimes impelled by racial, political, or religious motives. Only in those cases in which these two kinds of offense involved German or stateless victims were German courts permitted to exercise jurisdiction. Furthermore, offenses committed by individual perpetrators acting alone were not Crimes against Humanity, insofar as the latter required "systematic mass action." As the UN War Crimes Commission

10 Michael S. Bryant, Confronting the "Good Death": Nazi Euthanasia on Trial, 19451953 (Boulder, CO: University Press of Colorado, 2005), 109-110; Jörg Friedrich, Die kalte Amnestie: NS-Täter in der Bundesrepublik (Munich: Piper Verlag, 1994), 152-153. See also the text of the Landgericht Tübingen's discussion of perpetration under CCL No.10 in Adelheid Rüter, C. F. Rüter, H. H. Fuchs and Irene SagelGrande, eds., Justiz und NS-Verbrechen: Sammlung deutscher Strafurteile wegen nationalsozialistischer Tötungsverbrechen 1945-1966 (Amsterdam: Amsterdam University Press, 1968-1981), Lfd. Nr. 155a.

11 Friedlander, 31-32. 
wrote in its comparison of definitions of Crimes against Humanity under CCL No.10 and the Tokyo Charter, "systematic mass action, particularly if it was authoritative, was necessary to transform a common crime, punishable only under municipal law, into a crime against humanity, which thus became also the concern of international law." 12 As a practical matter, then, German courts in the immediate postwar era (1945-1951) prosecuted as Crimes against Humanity an assortment of "murder type" and "persecution type" offenses: the pogroms associated with the Night of Broken Glass in November 1938, denunciations by "grudge informers," killings of alleged "defeatists" at the end of the war, and political killings from the early years of the Nazi regime. What distinguished these offenses as Crimes against Humanity was the systematic mass action requirement: where this element was lacking, German courts typically charged their defendants solely with offenses under the German penal code. As far as the Nazis' excursions into mass extermination was concerned, CCL No. 10's prohibition of German jurisdiction over cases involving victims of Allied nations effectively removed the most sensational crimes of mass murder from German courts except one-the crimes of the Nazi "euthanasia" program. Euthanasia readily lent itself to German prosecution under Law No.10 because, first, the victims were in the main German nationals, and second, the murders were carried out pursuant to the orders of the Nazi government, thus satisfying the systematic mass action requirement. ${ }^{13}$

I would like to make our discussion a bit less abstract by examining how German courts appropriated CCL No. 10's definition of Crimes against Humanity in actual German trials after the war, until the Control Council forbade German prosecution under Law No. 10 in the fall of 1951. My focus will be on the trials of alleged Nazi offenders in French-occupied Baden in southwestern Germany, accused of participating in the Reich "Night of Broken Glass" pogrom in November 1938.

The allies assumed formal control of Baden on June 6, 1945, at which time much of the State was occupied by the French. What became known as the "French zone of occupation" was that portion of Baden south of the Karlsruhe-Stuttgart-Ulm autobahn, a zone that included the South Baden cities of Freiburg, Constance, Rastatt, Bühl, and Baden-Baden. In July 1945 the French military government relocated the State's ministries from Karl-

12 Excerpted in M. Cherif Bassiouni, Crimes against Humanity in International Law (The Hague: Kluwer, 1999), 36-37.

13 Friedlander, 32-33. 
sruhe to Freiburg, particularly the ministries of the interior, finance, and religious instruction. ${ }^{14}$

Like their British counterparts, the French military government required the German judiciary to charge Nazi offenders with Crimes against Humanity under CCL No. 10 when an alleged offense matched the elements set forth in Law No. 10's definition of the crime. In 1947, the French imposed a requirement on the Baden Ministry of Justice to deliver monthly reports on all cases involving alleged Crimes against Humanity that were being investigated or prosecuted by the Baden judiciary. The reports were to detail the following information: (1) the number of investigations pending at the beginning of the month for Crimes against Humanity, in which an indictment had not yet been issued; (2) the number of cases in which indictments for Crimes against Humanity had been issued, but which were not yet "legally final"; and (3) an index of new cases that had surfaced in which Crimes against Humanity were suspected. The reports had to be submitted no later than the sixth day of each month. ${ }^{15}$ The French later expanded this mandate to include information on proceedings against defendants that had become "legally final" (rechtskräftig abgeschlossen). The supplementary material was to include the names of the defendants, nature of the offense, date of verdict, and amount of punishment in the event the defendants were convicted. The French Military Government also demanded that the Germans inform them whether or not the accused was in preventive custody. ${ }^{16}$ The Baden Ministry of Justice in turn contacted the district attorneys' offices throughout southern Baden, requesting that they compile the information demanded by the French authorities.

On January 26, 1948, the district attorney of Constance responded to the Ministry of Justice's request with a list of proceedings for Crimes against Humanity that were still pending before the criminal justice authorities of Constance. The district attorney's response reveals the diversity

14 Paul Ludwig Weinacht, "Die politische Nachkriegsentwicklung und die Auseinandersetzungen um den Südweststaat," Badische Geschichte: Vom Großherzogtum bis zur Gegenwart, ed. Landeszentrale für politische Bildung Baden-Württemberg (Stuttgart: Konrad Theiss Verlag GmbH, 1987), 212-213.

15 Letter of the Baden Ministry of Justice to the Senior Public Prosecutor of Constance, dated November 7, 1947, concerning criminal proceedings for Crimes against Humanity, Staatsarchiv Freiburg [hereafter SF], F 178/1, No. 111.

16 Letter of the Baden Ministry of Justice to the Senior Public Prosecutor of Constance, dated January 23, 1948, concerning criminal proceedings for Crimes against Humanity, SF, F 178/1, No. 1109. 
of Nazi-era offenses investigated or tried in Baden after the war. They included cases involving the destruction of synagogues; denunciations; mistreatment of political opponents; mistreatment of Jews; collaboration in illegal sterilizations; shooting of political prisoners; discrimination against a woman for sexual intercourse with a Polish POW; abuses committed in concentration camps; and causing another person to be interned in a labor camp. The majority of suspected perpetrators in these cases had not yet been prosecuted, and many remained at large as of the date of the report. In addition to this list of pending cases, the district attorney of Constance submitted an index of legally final proceedings against defendants charged with Crimes against Humanity in the state court of Constance. The earliest case ended on February 2, 1947, involving three defendants charged with abusing preventive detainees in a concentration camp. Two of the three were convicted and sentenced to prison terms of 10 and 4 months, while the third was acquitted. ${ }^{17}$

A memorandum from the prosecutor general (Generalstaatsanwalt) in Freiburg, dated 7 December 1948, to the district attorney of Constance, discloses how Baden prosecutors interpreted Law No. 10's definition of Crimes against Humanity as it applied to Nazi-era offenses. In an earlier letter, the Constance DA had asked the prosecutor general whether the DA could prosecute denunciation cases as Crimes against Humanity, or whether instead these offenses should be processed in denazification proceedings (Spruchkammer). The prosecutor general replied with an extended excerpt of an advisory opinion authored by the Baden Ministry of Justice, which, in view of its acceptance by the French Military Government, was considered authoritative on the issue of how denunciations should be processed in Baden courts. In this excerpt, the Baden Ministry of Justice distinguished between two categories of denunciation, each of which was shaped by the unfolding radicality of the National Socialist police state. The first type of denunciation occurred between the Nazis' seizure of power in 1933 and the outbreak of war in September 1939. These cases were tried in Sondergerichte (special courts) on the basis of two Nazi penal statutes: $\mathbb{} 3$ of the Reich President's Decree for Protection against Treacherous Attacks on the Government of March 21, 1933; and $\$ S 1$ and 2 of the Treachery Law (Heimtückegesetz) of December 20, 1934. The Justice Ministry observed that the Nazi special courts meted out comparatively mild punishments for violations of these laws, consisting for most offenders of

17 Verzeichnis der schwebenden Verfahren wegen Verbrechens gegen die Menschlichkeit, SF, F 178/1, No. 1109 ff. 
short jail terms. Confinement in a concentration camp after serving the prison sentence typically did not ensue. In some instances, however-such as cases where the victims of denunciation were "politically prominent personalities" and Jews, for example-internment in a concentration camp after completion of sentence was customary. In such cases, the Ministry of Justice opined that the element of "other inhumane acts" (unmenschliches Handeln) under CCL No. 10, II 1(c), was satisfied both objectively and subjectively. On the objective level, the "inhumanity" of the deed met the statutory elements set forth in Law No. 10. On the subjective level, the Justice Ministry pointed out that the denouncer must have recognized that "the person being reported would be subjected to a proceeding that had little to do with justice, but served rather to eliminate ruthlessly all dissident thought." Hence, the state attorneys could indict these defendants for committing a Crime against Humanity under CCL No. $10 .^{18}$

Aside from the foregoing exception, the Justice Ministry indicated in the excerpted language that most of the cases of denunciation prior to September 1939 were to be processed in Baden denazification hearings. The Ministry distinguished the prewar category of denunciations, however, from those occurring after the onset of the war. After September 1939, said the Ministry, the special courts began punishing the objects of denunciation severely. The legal basis of the more draconian measures was a "special military criminal decree," which, although promulgated on August 8,1938 , did not become operative until August 26, 1939. $\$ 5$ of the decree contained a clause that made "undermining military power" (Zersetzung der Wehrkraft) punishable by death or, in milder cases, imprisonment. This offense applied to anyone who "publicly sought to impair or undermine the will of the German or allied peoples to able-bodied self-assertion.” The Nazi authorities induced district attorneys and courts to indict persons accused of making derogatory remarks about Hitler and critical remarks about the conduct or outcome of the war. The defendants would no longer be tried under the "treachery law" of December 1934, but on the basis of the "special military criminal decree" and its prohibition of actions that "undermined military power." Henceforth, in all cases tried under the special military decree, the convicted person was typically taken into cus-

18 Memorandum of the prosecutor general in Freiburg to the district attorney of Constance regarding Crimes against Humanity, dated November 29, 1948, SF, F 178,1, No. 111, 1-3. 
tody by the Gestapo after completion of the prison term, and thereafter interned in a concentration camp. ${ }^{19}$

According to the Justice Ministry, the decisive turning point in these "inhumane proceedings" occurred sometime in 1941. From this time forward, the growing number of convictions under the special military decree reflected a rigor of punishment lacking in the prosecution of similar offenses between 1933 and 1940. The kinds of offenses punished with a jail term of a few months in the earlier period now resulted in lengthy prison terms and frequently the death penalty, particularly after the military defeat at Stalingrad in 1943. In the words of the Justice Ministry, "anyone accusing others of insulting or defeatist statements from 1941 onward had to be aware that the person accused would suffer thoroughly inhumane treatment [by the authorities]." 20

In order to distinguish these two species of denunciation, the Justice Ministry cited the 1933 case of a man named Reupold, denounced to the authorities on the basis of $\$ 3$ of the Reich President's Decree. The special court sitting in Mannheim convicted Reupold and sentenced him to a four-month jail term. After a couple months, he received probation for good behavior and was released from jail. In this case, the Justice Ministry reasoned, there was no question that the man who had reported Reupold to the authorities had in fact done so, or that he was deserving of punishment for his misdeed. This notwithstanding, the Justice Ministry doubted that such a denunciation could be regarded as a "Crime against Humanity." Presumably, the relative mildness of Reupold's punishment did not fulfill the element of "inhumane action" under Law No. 10. The Ministry's doubts received further confirmation from a State decree published in March 1947, which stated that denouncers who harmed others by reporting their political opposition to the Nazi authorities could be characterized as "activists" by the denazification courts. The denazification courts could then punish the denouncer with imprisonment or confiscation of property. Processing cases like Reupold's in denazification proceedings was, finally, preferable to a criminal trial because of the risk that the denouncer could be acquitted. After excerpting the advisory opinion of the Justice Ministry, the prosecutor general's memorandum recommended that in such cases the state court enter a dismissal order, to which the judge should attach his reasons for dismissing the case. ${ }^{21}$

19 Ibid., 3-4.

20 Ibid., 4.

21 Ibid., 5-6. 
The views of the Ministry of Justice show that Baden courts were expected to prosecute Nazi-era crimes as Crimes against Humanity when they met the element of "inhumane conduct" under CCL No. 10. Whether or not a defendant's actions fulfilled the element of "inhumaneness" under Law No. 10 was, however, by no means the only consideration of Baden courts in prosecuting Crimes against Humanity against German defendants. In responding to the legal arguments of defendants accused of participation in the nationwide pogrom of November 10, 1938, southwest German courts expounded additional juridical theories that governed when Crimes against Humanity would be charged against Nazi defendants.

The indictments in the Baden trials of the November 1938 pogrom defendants are notable for their amalgam of national and international law. ${ }^{22}$ Depending on the facts of the case, defendants were usually accused of (1) a Crime against Humanity under CCL No.10, insofar as evidence suggested the defendant's actions stemmed from political or racial motives; (2) Breach of the Public Peace (Landfriedensbruch), for disrupting public order; and (3) breaking and entering (Hausfriedensbruch), when the defendant forcibly entered a synagogue or Jewish dwelling, typically for the purposes of vandalizing, plundering, or setting it on fire. These three fundamental charges were sometimes joined to additional offenses, such as "incitement to class struggle" (Anreizung zum Klassenkampf), "destruction of property" (gemeinschädliche Sachbeschädigung), or "false imprisonment" (Freiheitsberaubung). All of these charges except Crimes against Humanity were considered violations of the German penal code as it existed at the time of the offense-that is, the Baden courts insisted that the criminal law remained operative during the reign of the Nazi Party, and in spite of the Nazis' endorsement of the pogrom.

In the Sulzburg synagogue case (tried in December 1947), the defendants were charged with crimes against the male Jewish citizens of the town, whom Gestapo officials ordered assembled on November 10, 1938, and marched on foot to the prison in nearby Müllheim. As Sulzburg's Jewish men marched off to prison, the synagogue, the Jewish school, and nearly all of the Jewish houses and businesses were vandalized and plundered. One of the defendants implicated in the destruction of Jewish property

22 Although Crimes against Humanity under Law No. 10 were technically "national" law (because the Allied Control Council was the sovereign lawmaking authority in Germany), the definition was based on the London Charter, which was international law. Due to its roots in international humanitarian law, then, a Crime against Humanity under Law No. 10 was arguably premised on international law. 
was a man named Köhler. The Landgericht Freiburg convicted him of a Crime against Humanity because his offense-breaking out the windows of a Jewish confection store with a walking stick-was politically and racially motivated, thus fulfilling the elements under CCL No. 10. By contrast, in assessing the guilt of a co-defendant named Pfister, who lived in a neighboring town and drove to Sulzburg on the morning of the pogrom, the court acquitted him of a Crime against Humanity because it was unconvinced that he had joined the Sulzburg mob for racial or political reasons; rather, the court thought it more likely that his presence at the scene of the pogrom was actuated by curiosity and obedience to the orders of his superior to drive to Sulzburg that morning. ${ }^{23}$

The trial of 16 defendants accused of participating in the November pogrom in the Baden city of Offenburg provides further insight into the Baden judiciary's appropriation of Crimes against Humanity in German courtrooms. The Offenburg pogrom involved the destruction of the synagogue and its contents, the arrest and jailing of Offenburg Jews before their transportation to the Dachau concentration camp, and the vandalization of a Jewish café by an anti-Jewish mob. For their alleged roles in one or more of these stages of the pogrom, the defendants were charged with various permutations of Crimes against Humanity, aggravated breach of public order, aggravated breaking and entering, incitement to class struggle, destruction of property, and false imprisonment. In its discussion of the law applicable to defendants' offenses, the state court of Offenburg noted that German courts after 1945 had augmented CCL No. 10's definition of Crimes against Humanity to include "every act of cruelty against human existence as well as every act that degraded human worth and destroyed human culture, insofar as they were committed under the influence of a political will to power and of a dominant idea pursued by it." The state court went on to quote the jurist Güde, who had glossed Law No. 10's reference to racially, politically, or religiously motivated persecution as follows: "Violation of human rights through terroristic abuse of state or political power, inflicted on political, religious, or racial enemies." 24

23 Strafsache gegen den Metzger Alfred Spath aus Laufen u.a., SF, 176/22, No. 5/1/172 ff. Acquitted of Crimes against Humanity and of plundering, Pfister was convicted of breach of the public peace.

24 Urteil in Strafsache gegen Oskar Wiegert u.a., SF, F 176/4, No. 19/22/060 (quoting OLG Köln in Neue Juristische Wochenschrift 2 (1947), 70; and Güde, Deutsche Rechtszeitschrift (1947), 111). 
The Offenburg state court had little trouble classifying the pogrom as a Crime against Humanity, insofar as it was driven by racial and religious hatred toward the Jews. Moreover, the court stressed that the pogrom was not a purely "local" action of disaffected fanatics, but rather a "planned operation against the Jews carried on throughout Germany," orchestrated by the highest levels of the Nazi government. The court emphasized that the pogrom had to be comprehended in its totality as a phenomenon instigated and guided by an anti-Semitic political system; individual charges of disturbing the peace, false arrest, etc., should not, the court cautioned, be allowed to obscure the essential unity of the crime. Further, the court insisted that the illegality of the pogrom was clearly recognizable to all the defendants. No "mistake of law" (Verbotsirrtum) would shield them from their contributions to the assault on Offenburg's Jews. ${ }^{25}$

It was, of course, in the defendants' interest to preempt application of Law No. 10's Crimes against Humanity to their actions, chiefly because Law No. 10 prescribed a higher range of punishment than did German law, and because No. 10 discounted subjective factors in assessing an actor's liability under the statute. If the Offenburg pogrom defendants expected the court to dismiss the Crimes against Humanity charge, they were disappointed. Citing the famed jurist Gustav Radbruch, the state court held that CCL No. 10, as a decree of the "highest legislative authority" in Germany, was binding law alongside the German penal code. Accordingly, the court announced its intention to construe the acts of the defendant in connection with the pogrom as a "unified course of action," as required by Law No. 10. This meant, in effect, that the court would not divide the pogrom into individual crimes performed by autonomous actors, but would consider the pogrom as a unitary and continuous crime involving the defendants' myriad contributions. ${ }^{26}$ The court furthermore refused to suspend application of Crimes against Humanity based on the objection of

25 Ibid., 19/22/060-062.

26 Ibid., 19/22/062. German law distinguishes between "ideal" and "real" concurrence in instances of collective criminality. Ideal concurrence portrays all actors involved in the criminal enterprise as being liable for acts carried out in furtherance of it, not just for their own individual contributions. Real concurrence, by contrast, foregrounds the individual contributions of the actors within the general scheme. Inasmuch as German courts interpreted CCL No.10 as requiring the doctrine of ideal concurrence, Law No. 10 bears comparison with the vicarious criminal liability imposed by the law of conspiracy, which formed the backbone of the Allies' case against the major war criminals at Nuremberg. On the distinction between the two forms of concurrence, see Devin O Pendas, The Frankfurt Auschwitz Trial, 1963-1965: Genocide, History, and the Limits of the Law (Cam- 
retroactive prosecution: in the court's view, to nullify Law No. 10's application to Nazi crimes based on the historic prohibition of retroactive legislation in German law would evacuate Law No. 10 of "any practical meaning." The court noted that in any event Anglo-Saxon common law did not unconditionally forbid retroactive laws. ${ }^{27}$

In none of the pogrom trials prosecuted in French-occupied Baden did the accused's defense prevail when based on arguments of CCL No. 10's retroactivity. When a defense to a charge under Law No. 10 succeeded, it was usually because the court found the evidence of criminal wrongdoing insufficient, either because witnesses recanted their earlier statements or the defendant's actions did not fulfill the elements of a Crime against $\mathrm{Hu}$ manity. In a subsequent trial involving a second group of alleged participants in the Offenburg pogrom, all five of the defendants were acquitted of Crimes against Humanity, breach of public peace, and false imprisonment for their roles in arresting Offenburg Jews and escorting them to the train station, whence they were transferred to Dachau. During trial the witnesses against the defendants recanted their incriminating testimony, leaving the defendants' own narratives of the events unrefuted. According to their version, the accused did not arrest and escort the Jews for motives of racial or religious hatred, but in order to protect the Jews from a mob enraged over the assassination of the German diplomat, Ernst vom Rath. In the absence of proof that they had acted from invidious motives, the court acquitted the five defendants of Crimes against Humanity. ${ }^{28}$

German prosecution of Nazi defendants for Crimes against Humanity would continue until September 1951, when the Allies, at the urging of the Germans, prohibited German courts from applying CCL No. 10. At this time, the British and French revoked the authorization under CCL No. 10, Art. III, No. 10, which had enabled the Germans to charge defendants with Crimes against Humanity. From that time forward, West Ger-

bridge: Cambridge University Press, 2006), 197; Fritz Bauer, "Ideal- oder Realkonkurrenz bei nationalsozialistischen Verbrechen?”, Juristenzeitung 22 (1967), 627.

27 Urteil in Strafsache gegen Oskar Wiegert u.a., SF, F 176/4, No. 19/22/062.

28 Urteil in Strafsache gegen Hans Jockers u.a., SF, F 179/6, P.3, No. 12. The Offenburg court also acquitted the defendants of breach of public peace and false imprisonment on the theory that the SS became auxiliaries to local police forces on November 10 for the purpose of maintaining order. Because the defendants participated in an apparently legitimate police function in taking into custody and escorting the Jews, they had a reasonable belief that their actions were legal. 
man courts would apply only German domestic criminal law in the trials of accused Nazi war criminals. ${ }^{29}$

\section{Conclusion}

As we have seen, charging Nazi offenders with Crimes against Humanity under CCL No. 10 held several advantages for prosecutors. Not only did Law No. 10 afford prosecutors greater flexibility in charging defendants and securing more severe punishment than German domestic law did, but it rejected German law's distinction between perpetrators and accomplices. This meant that all participants in the crime were jointly liable as perpetrators for the acts of their confederates that furthered the criminal scheme, just as they would be on a theory of conspiracy.

None of this is surprising if we consider that CCL No. 10 was based on the doctrine of conspiracy. When the Germans applied and interpreted Law No. 10's definition of Crimes against Humanity in their own courtrooms, they construed it as requiring a focus on the defendants' vicarious liability for the crimes of their co-conspirators in the officially sanctioned criminal enterprise. In the language of German law, German courts endorsed a theory of "ideal concurrence" to evaluate the criminality of their defendants' acts. Learned Hand once commented that the crime of conspiracy was "the darling of the modern prosecutor's nursery," because it enabled prosecutors to hold defendants criminally liable for the actions of their co-actors. ${ }^{30}$ Built on the doctrine of conspiracy, Law No. 10 and its appropriation in German courts was no less a "darling" to the Baden judiciary in the immediate postwar era.

The tide turned decisively in favor of Nazi defendants, however, when the Allied Control Council prohibited German courts from charging them under Law No. 10 after August 1951. Henceforth, the crimes of Nazi offenders would be adjudicated in West German courts under German criminal law, not the more stringent law of the Allied Control Council. Although applying domestic law enabled German courts to avoid the ex post facto challenge frequently heard in trials based on Law No. 10, German criminal law was a boon to many Nazi defendants. First, in contrast with

29 Memorandum from the Baden Justice Ministry to the District Attorney of Constance, December 6, 1951, regarding criminal proceedings under CCL No. 10, SF, F 178/1, No. 1112; excerpt from the Baden Ministerial Journal December 28 (1951), No. 25, SF, F 178/1, No. 1112. See also H. Friedlander, 32; Rückerl, 40.

30 Harrison v. United States, 7 F.259 (2d Cir. 1925). 
Law No. 10, German law distinguished between perpetrators and accomplices based on the subjective disposition of the actor. Such an approach did not impute liability based on the acts of a defendant's confederates, as Law No. 10 had done, but purely with regard to the offender's individual actions and psychological disposition. Second, German courts in their trials of Nazi crimes adopted the approach of "real concurrence," that is, they focused on the defendant's real actions in isolation from the context in which these acts were committed. The emphasis on subjectivity and the adoption of real concurrence in assessing the individual acts of offenders clearly benefited accused war criminals. When these post-1951 developments are considered along with the expiration of statutes of limitations governing Nazi-era crimes in 1955 and again in 1960, we can appreciate why Nazi war crimes trials subsided so dramatically between 1951 and the late 1950s. Without question, German political and international geopolitical events contributed to this precipitous dropoff, as did the German judiciary's own ambivalence toward prosecuting Nazi crimes. In studying the German confrontation with Nazi criminality in the postwar years, however, the limitations of German domestic law should be given their proper due. 